\title{
Impact of gold nanoparticles shape on their cytotoxicity against human osteoblast and osteosarcoma in in vitro model. Evaluation of the safety of use and anti-cancer potential
}

\author{
Karol P. Steckiewicz ${ }^{1}$ - Ewelina Barcinska ${ }^{1}$ - Anna Malankowska ${ }^{2}$ - Agata Zauszkiewicz-Pawlak ${ }^{3}$. \\ Grzegorz Nowaczyk $^{4} \cdot$ Adriana Zaleska-Medynska $^{2} \cdot$ Iwona Inkielewicz-Stepniak $^{1}$
}

Received: 24 September 2018 / Accepted: 10 January 2019 / Published online: 12 February 2019

(c) The Author(s) 2019

\begin{abstract}
Due to development of nanotechnology and gold nanoparticles (AuNPs) increasing use in different areas of medicine, especially in oncology, better understanding of their potential cytotoxicity is necessary to protect patients safety. Shape and size of AuNPs is an important modulator of their cytotoxicity. Therefore, we investigated the cytotoxicity of AuNPs rods ( $\approx 39 \mathrm{~nm}$ length, $18 \mathrm{~nm}$ width), AuNPs stars $(\approx 215 \mathrm{~nm}$ ) and AuNPs spheres $(\approx 6.3 \mathrm{~nm}$ ) against human fetal osteoblast (hFOB $1.19)$, osteosarcoma (143B, MG63) and pancreatic duct cell (hTERT-HPNE) lines by MTT and neutral-red uptake assay. Moreover, influence of AuNPs on level of proapoptotic protein (Bax) and anti-apoptotic protein (Bcl-2) was measured by western blot. Cellular uptake of nanoparticles and ultrastructure changes were examined by transmission electron microscopy (TEM). In the present study we have proven that AuNPs stars are the most cytotoxic against human cells. We observed that cancer cells are more susceptible to AuNPs cytotoxic effect. Furthermore, AuNPs rods and AuNPs stars caused increased expression of Bax and decreased expression of Bcl-2 protein in osteosarcoma cells. We found that AuNPs penetrated through the cell membrane and caused ultrastructural changes. Our results clearly demonstrated that the cytotoxicity of AuNPs was shape-dependent. AuNPs stars with the highest anti-cancer potential were also the most cytotoxic type of tested NPs, whereas AuNPs spheres which appears to be the safest one had small anti-cancer potential.
\end{abstract}

Supplementary information The online version of this article (https:// doi.org/10.1007/s10856-019-6221-2) contains supplementary material, which is available to authorized users.

Iwona Inkielewicz-Stepniak

iinkiel@gumed.edu.pl

1 Department of Medical Chemistry, Medical University of Gdansk, Debinki 1, 80-211 Gdansk, Poland

2 Department of Environmental Technology, Faculty of Chemistry,
University of Gdansk, Wita Stwosza 63, 80-308 Gdansk, Poland

3 Department of Histology, Medical University of Gdansk, Debinki 1, 80-211 Gdansk, Poland

4 NanoBioMedical Center, Adam Mickiewicz University, 61-614 Poznan, Poland 


\section{Graphical Abstract}

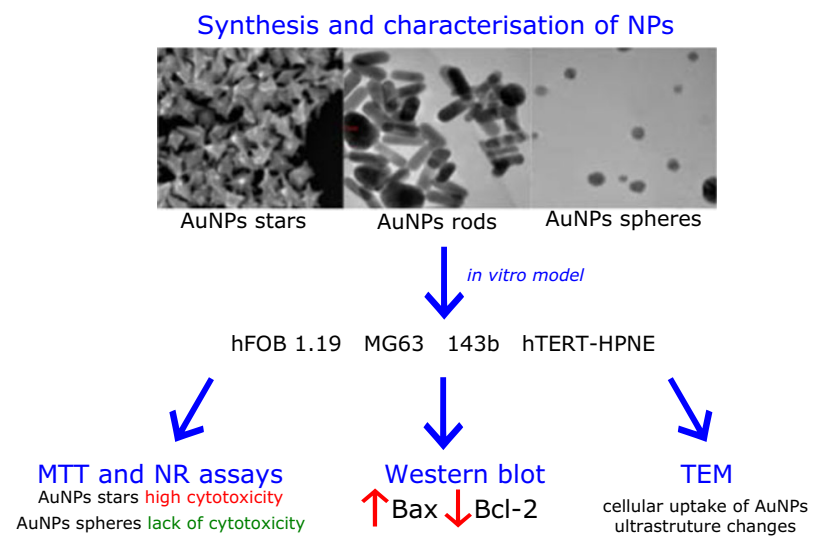

2 Materials and methods

\section{Introduction}

In 21st century nanotechnology is rapidly developing and its achievements may be used in biology and medicine. Nobel metals nanoparticles seem to be particularly interesting in biomedical application. Gold nanoparticles (AuNPs) due to small size, high surface area to volume ratio and good biocompatibility have great potential for a wide range of applications in medicine [1]. Furthermore, there are many different shapes of AuNPs, they can have one, two or even three dimension which also expand variety of potential usages [2]. It is also important that AuNPs can penetrate through biological barriers and cellular membranes. [3]. The unique properties causes that AuNPs are widely applied in diagnostic and therapy, from medical imaging [4] to bacteria and viruses detection [5, 6]. They are also component of thermal ablation [7] and cancer immunotherapy [8]. Moreover, AuNPs may be part of drug delivery systems [9]. Unfortunately, it has been shown that AuNPs can accumulate in vacuoles and induce cell death $[4,10]$. In addition, AuNPs may cause increased synthesis of proapoptotoic proteins [3].

There are not enough studies which compare different shapes of AuNPs on the same cell lines using identical methodology and because of variety of potential bioapplication of AuNPs, we decided to assess the impact of shape and size of AuNPs on human cells in in vitro model. Cytotoxicity of different concentration of AuNPs rods, AuNPs stars and AuNPs spheres were tested on four cell lines: hFOB 1.19, 143B, MG63 and hTERT-HPNE. According to our knowledge it is the first study, which compares impact of shape of AuNPs on their cytotoxicity against human osteoblast, osteosarcoma and pancreatic duct cells. The main purpose of this research was to assess the cytotoxic activity against cancer cells as well as the safety of use.

\subsection{Chemical reagents}

Cetyltrimethylammonium bromide (99\%, CTAB), sodium borohydrate $(>98 \%)$, L-ascorbic acid $(99 \%$, AA), silver nitrate (99\%), tannic acid were purchased from Sigma Aldrich. Gold (III) chloride trihydrate was purchased from Alfa Aesar.

\subsection{Synthesis of AuNPs}

The AuNPs spheres, rods and stars were prepared and characterized as described in our previous articles [11, 12], with some modification indicated below.

\subsubsection{Au nanospheres}

AuNPs spheres were obtained by mixing solution of tannic acid $\left(3 \mathrm{ml}, 6 \times 10^{-3} \mathrm{M}\right)$ and hot solution of $\mathrm{HAuCl}_{4}(50 \mathrm{ml}$, $1.3 \times 10^{-4} \mathrm{M}$ ) for $1 \mathrm{~min}$.

\subsubsection{Au nanostars}

Firstly, an aqueous solution of gold precursor $(0.2 \mathrm{~mL}, 0.01$ $\mathrm{M})$ was added to the $0.1 \mathrm{M} \mathrm{CTAB}$. After that $0.01 \mathrm{M}$ $\mathrm{AgNO}_{3}$ solution and $0.1 \mathrm{M}$ AA solution were added. In the next step, $20 \mu \mathrm{L}$ of AuNPs stars solution was added. The obtained solution was kept for $20 \mathrm{~h}$ at $28-30^{\circ} \mathrm{C}$. The color of the solution became blue indicating the formation of AuNPs stars. The products were isolated and washing with water.

\subsubsection{Au nanorods}

Firstly, seed solution was obtained by stirring $0.2 \mathrm{M}$ CTAB solution with $0.5 \mathrm{mM}$ gold precursor and $0.6 \mathrm{ml}$ of $0.01 \mathrm{M} \mathrm{NaBH}_{4}$. The solution was kept at $30^{\circ} \mathrm{C}$ for $4 \mathrm{~h}$. 
Then, AuNPs rods were prepared by mixing $5 \mathrm{~mL}$ CTAB, $40 \mathrm{mM} \mathrm{AgNO} 3$ solution, $5 \mathrm{~mL} \mathrm{HAuCl}_{4}$ solution followed by the addition of $70 \mu \mathrm{L}$ AA. The final step was the addition of $12 \mu \mathrm{L}$ of the seed solution to the growth solution at $30^{\circ} \mathrm{C}$. The AuNPs rods were isolated and washed with water.

\subsection{Characterization of synthesized AuNPs}

UV-Vis absorption spectra were obtained using a spectrophotometer Thermo Scientific Evolution 220 (Waltham, MA, USA) in the range of 200-1400 $\mathrm{nm}$. The morphology and distribution size of obtained particles were observed using SEM Jeol 7001TTLS microscope operated at $12 \mathrm{kV}$ and HR-TEM (ARM $200 \mathrm{~F}$ ) operating at $200 \mathrm{kV}$. For HRTEM sample preparation, a drop of a aqueous gold dispersion was deposited on cooper grid covered with a formal-carbon membrane. For SEM analysis aqueous solution of AuNPs was deposited on cleaned silicon wafer substrates.

\subsection{Cell culture}

Cell lines were obtained from the American Type Culture Collection (ATCC). Human fetal osteoblast cell line (hFOB 1.19, ATCC CRL-11372), was cultured in 1:1 mixture of Ham's F12 Medium and Dulbecco's Modified Eagle's Medium (PanBiotech, Germany), by supplemented $2.5 \mathrm{mM}$ L-glutamine, $10 \%$ fetal bovine serum (FBS) and $1 \%$ of penicillin/streptomycin (P/S). Human bone osteosarcoma cell line (143B, ATCC CRL 8303) was cultured in Minimum Essential Medium (Eagle) in Earle's BSS (PanBiotech, Germany) with $0.015 \mathrm{mg} / \mathrm{mL}$ 5-bromo-2'deoxyuridine, $2.5 \mathrm{mM}$ L-glutamine, with an addition of $10 \% \mathrm{FBS}$ and $1 \%$ of $\mathrm{P} / \mathrm{S}$. Human osteosarcoma cell line (MG-63, ATCC CRL-1427) was cultured in Eagle's Minimum Essential Medium (PanBiotech, Germany) supplemented by $10 \%$ FBS and $1 \%$ of P/S. hTERT-HPNE cell line (pancreatic duct cells) (ATCC CRL-4023) was cultured in medium which consist of 75\% Dulbecco's Modified Eagle's Medium without glucose (Sigma Aldrich), 25\% of M3 Base (Sigma Aldrich, USA), 5\% of FBS, $1 \%$ of antibiotics, 5.5 $\mathrm{mM}$ D-glucose, $2 \mathrm{mM}$ of L-glutamine, $1.5 \mathrm{~g} / \mathrm{L}$ sodium bicarbonate and $10 \mathrm{ng} / \mathrm{mL}$ human recombinant EGF. All cells were cultured under standard conditions. All cell cultures were cultured at $37^{\circ} \mathrm{C}$ in a humidified atmosphere of $5 \% \mathrm{CO}_{2}$. Cells were maintained in $75 \mathrm{~cm}^{2}$ tissue culture flask. The medium was replaced every $48 \mathrm{~h}$. When confluent cells were detached with trypsin-EDTA solution and subcultured into a newer flask. Subcultivation ratio was 1:4 for hFOB 1.19, 143B, and MG-63 cells and 1:8 for hTERTHPNE cells.

\subsection{Treatments}

hFOB 1.19, MG-63, 143B and hTERT-HPNE cells were treated using AuNPs in the three different shapes rods, stars, and roods for $24 \mathrm{~h}$. Concentrations used in experiments were determined by preliminary studies (in range of 0.3-5 $\mu \mathrm{g} / \mathrm{mL})$. Each time, just before, experiment AuNPs were diluted in FBS-free media and shaken well to ensure equal dispersion of AuNPs in solution. AuNPs solutions were shaken before use to avoid agglomeration of nanoparticles. Control samples were treated with AuNPs-free, FBS-free culture media. The medium was not change during the incubation process.

\subsection{MTT viability assay}

MTT assay was used to determine cell viability. Cells were seeded in 96 plates at a density of $1 \times 10^{4}$ cell per well. After $24 \mathrm{~h}$ cells were treated as described in Treatments section. For rods, stars and spheres concentration $0.3,0.6$, $1.2,2.5$ and $5 \mu \mathrm{g} / \mathrm{mL}$ were examined. After $24 \mathrm{~h}$ incubation the media was supplemented of water-soluble tetrazolium salt [3-(4,5-dimethylthiazol-2-yl)-2,5-diphenyltetrazolium bromide (final concentration $0,45 \mathrm{mg} / \mathrm{mL}$ ). Next, microplates were incubated at $37^{\circ} \mathrm{C}$ in $5 \% \mathrm{CO}_{2}$ for $2 \mathrm{~h}$. After incubation media was replaced and formazan crystals were diluted in $100 \mu \mathrm{L}$ of dimethyl sulfoxide (DMSO). After 15 min, cell viability was assessed by measuring absorbance at $540 \mathrm{~nm}$ (reference $630 \mathrm{~nm}$ ) using microplate reader. Viability was determined as a percentage of control (viability of control cells was set as $100 \%$ ). Absorbance values were corrected with blank NPs.

\subsection{Neutral red uptake viability assay}

The assay is based on the ability of viable, uninjured cells to accumulate neutral red dye solution in lysosomes. Cells were seeded in 96 plates at a density of $1 \times 10^{4}$ cell/well. After $24 \mathrm{~h}$ cells were treated as described in treatments section. For rods, stars and spheres concentration 0.3, 0.6, 1.2, 2.5 and $5 \mu \mathrm{g} / \mathrm{mL}$ were examined. Next, to each wall, the neutral red dye was added to final concentration of $100 \mu \mathrm{g} / \mathrm{mL}$. Then, microplates were incubated at $37^{\circ} \mathrm{C}$ in $5 \% \mathrm{CO}_{2}$ for $2 \mathrm{~h}$ and medium was removed, cells washed with phosphate buffered saline (PBS) $(\mathrm{NaCl} 0.138 \mathrm{M}, \mathrm{KCl} 0.0027 \mathrm{M}, \mathrm{pH}=7.4$, without $\mathrm{Ca}^{2+}$ and $\mathrm{Mg}^{2+}$ ) and fixated with neutral red fixative solution $\left(0.5 \%\right.$ formaldehyde, $\left.0.1 \% \mathrm{CaCl}_{2}\right)$. Subsequently, the dye was dissolved in neutral red solubilization solution (50\% ethanol, $1 \%$ acetic acid) and gentle shaking for $10 \mathrm{~min}$. Cell viability was assessed by measuring of absorbance at $540 \mathrm{~nm}$ (reference $630 \mathrm{~nm}$ ) using microplate reader. Viability was determined as a percentage of control 
(viability of control cells was set as $100 \%$ ). Absorbance values were corrected with blank NPs.

\subsection{Western blotting}

Western blotting was used to examining the influence of AuNPs on pro and anti-apoptotic proteins levels. Briefly, MG-63 and 143B cells were treated with nanoparticles in FBS-free media as described in Treatments section. For AuNPs rods concentrations of NPs were 1 and $2 \mu \mathrm{g} / \mathrm{mL}$, for AuNPs stars concentrations were 0.1, 0.3, 0.6, $1 \mu \mathrm{g} / \mathrm{mL}$. Cells were seeded in $10 \mathrm{~cm}^{2}$ Petri dish. When confluence was about $80-90 \%$ cells were treated with AuNPs for $24 \mathrm{~h}$ and Western blotting analysis was performed according to protocol previously established by our team [13]. Before electrophoresis protein level was measured by Bradford method [14]. Rabbit polyclonal anti-Bcl-2 and anti-Bax IgG antibodies and anti-rabbit secondary antibodies were used (Santa Cruz, USA). Dilution of antibodies according to manufacturer protocol was 1:250 for Bax; 1:100 for Bcl-2 and 1:20000 for anti-rabbit secondary antibodies. $\beta$-actin was used as loading control. Immunoactive proteins level were examined by chemiluminescence (ECL) Westernblotting kit.. Proteins levels were quantified using densitometry software (ImageQuant Software, GE Healthcare, UK).

\subsection{TEM analysis}

Cellular uptake of nanoparticles and ultrastructure changes were examined by transmission electron microscopy (TEM). Briefly, hTERT-HPNE cells were cultured in 10 $\mathrm{cm}^{2}$ Petri-dish. When 80-90\% confluent cells were treated with AuNPs rods and stars in concentration 10 and $50 \mu \mathrm{g} /$ $\mathrm{mL}$ as described in Treatment section. After $24 \mathrm{~h}$ of incubation cells were fixated with $2.5 \%$ glutaraldehyde in 0.1 $\mathrm{mM}$ sodium-cocodylate buffer. Then cells were detached and centrifuged. Cells plates was postfixaited in $2 \%$ osmium tetroxide. Next dehydration in graded solution of ethanol was applied. Cell were infiltrated with propylen dioxide, eopn mixture and pure eopn. Then cell were settled to polymerise. Prior to TEM examination at $100 \mathrm{kV}$ (JEM 1200EX II, Jeol, Japan), ultra-thin section (Reichert OmU3 ultramicrotome, Austria), were contrasted by uranyl acetate and lead citrate.

\subsection{Statistical analysis}

All statistical analysis was performed with GraphPad Prism 5 software (GraphPad Software, Inc, USA). All data on graphs are presented as the mean \pm standard error of 3-4 independent experiments. Statistical analysis was determined by one-way analysis of variance (ANOVA) and
Tukey's posthoc test. The $\mathrm{IC}_{50}$ was calculated by analyzing of non-linear regression $\log$ (inhibitor) vs normalized response.

\section{Results and discussion}

\subsection{Morphology of AuNPs}

The morphology of prepared samples was studied by SEM and TEM microscopy. The average gold size was calculated from average size of 100 AuNPs using ImageJ Analysis Software. As clearly shown (Fig. 1a-c), the AuNPs stars have well-developed with the tip-to-tip diameter in range $170-260 \mathrm{~nm}$ with various numbers of tips. The major fraction of AuNPs stars appears with an average size of $200 \mathrm{~nm}$. SEM analysis also showed that all of AuNPs stars particles have a branched structure. The fractions in diameter about $170 \mathrm{~nm}$ and $260 \mathrm{~nm}$ represented a small part in the test sample. The AuNPs rods with narrow size distribution of $\sim 45 \mathrm{~nm}$ in length and $\sim 16 \mathrm{~nm}$ diameter are shown in Fig. 1d-f. The major fraction of AuNPs rods appears with an average length size $\sim 45 \mathrm{~nm}$. Moreover, observation at high magnification shows that the surface of the AuNPs rods is smooth. The TEM results also confirmed that small fraction of the formed particles have a spherical shape. Nikoobakht et al. showed that formation of a large fraction of spherical particles can be overcome by use of a (CTAB)-capped seed instead of a citrate-capped one [15]. After reduction of gold precursor by tannic acid, the gold AuNPs spheres with diameters in the range from 6 to approximately $22 \mathrm{~nm}$ were formed (Fig. 1g-i). AuNPs spheres were rather uniform in shape. The major fraction of AuNPs spheres appears with an average size equaled to 14 nm.

\subsection{UV-Vis properties of gold nanoparticles}

The UV-Vis properties of prepared gold nanoparticles were characterized by UV-Vis spectroscopy in range 200-1400 nm (Fig. 2). The AuNPs exhibit a distinct optical feature commonly referred to as localized surface plasmon resonance (LSPR). The position and intensity of the LSPR band depends on the size and surface morphology of gold particles (a-b). For AuNPs spheres, the plasmon peak shifts to higher wavelengths with increasing particle size, from the visible to the IR light [16]. The absorption band at $530 \mathrm{~nm}$ was observed for AuNPs spheres and this peak position comes from small particles, which is also confirmed by TEM results. According to the literature, the one plasmon band around $527 \mathrm{~nm}$ is corresponding to the spherical gold with size about $20 \mathrm{~nm}$ [17]. For AuNPs stars a plasmon band ranging from 500 to $1400 \mathrm{~nm}$ was observed. 

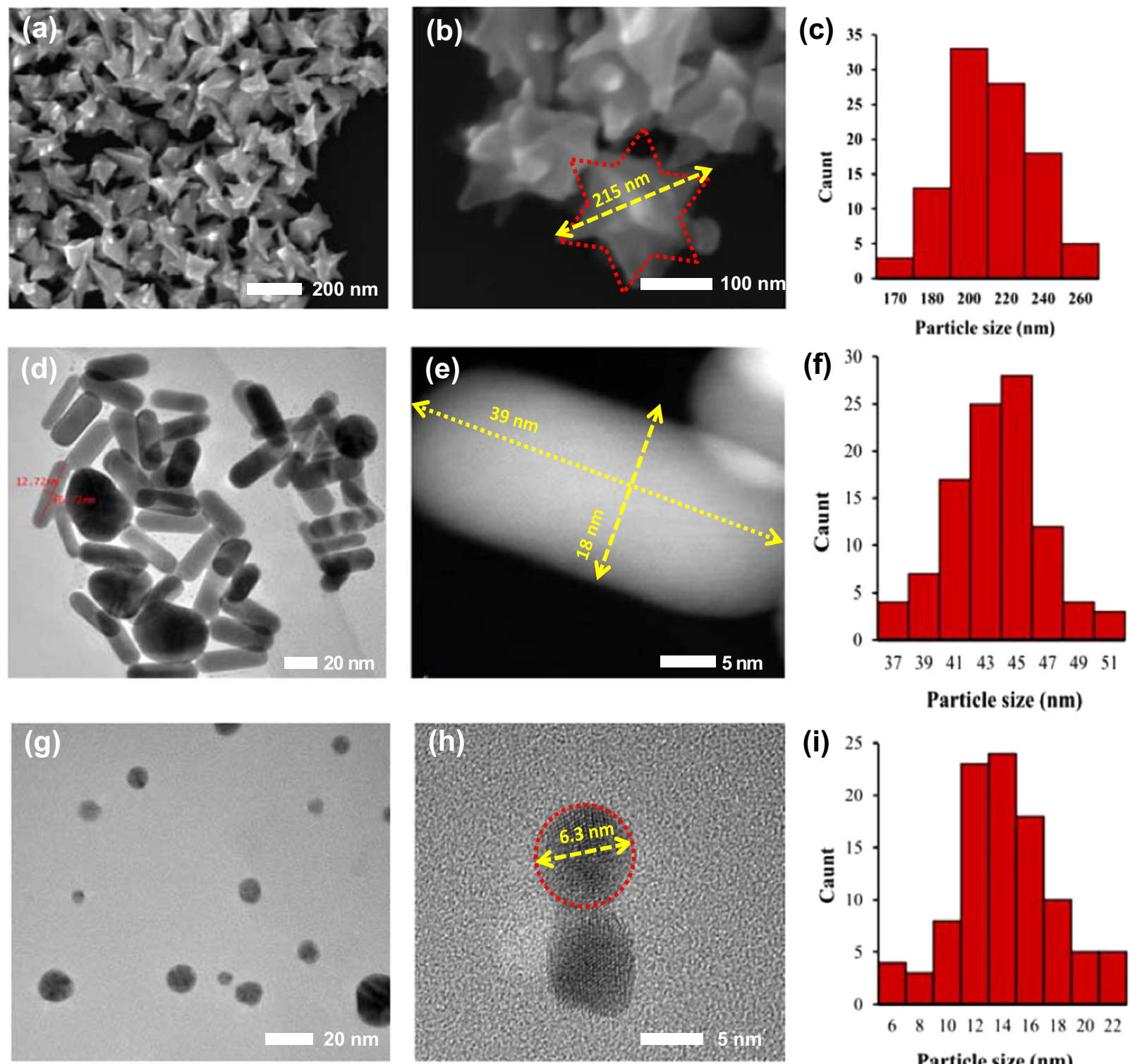

Particle size (nm)

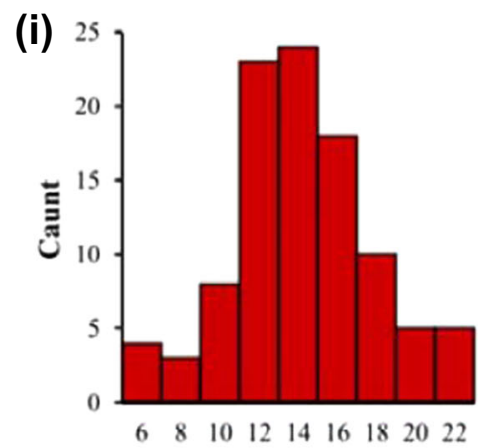

Particle size (nm)

Fig. 1 Morphology (TEM/SEM images) and average size distribution of a-c AuNPs stars, $\mathbf{d}-\mathbf{f}$ AuNPs rods, $\mathbf{g}-\mathbf{i}$ AuNPs spheres

According to the literature, the absorption peak in the IR region depends on the number of tips of gold nanoparticles [18]. It is know that the shape of the branches and their each other interaction of AuNPs stars determine the absorption ranges [16]. For AuNPs rods, typically two plasmon resonances are observed. The transverse and longitudinal LSPR extinction peaks located around 520 and $680 \mathrm{~nm}$ respectively, was observed for AuNPs rods prepared using seedmediated synthesis. Appearance of transverse and longitudinal plasmon resonances is evident of the formation of AuNPs rods. Further, the presence of two characteristic peaks suggests that the sample was homogenous.

\subsection{Determination of cell viability}

Analysis of MTT assay and NR assay results have shown that shape and concentration of nanoparticles has an impact on their cytotoxicity (Fig. 3)

The highest impact on cells survival had AuNPs stars and decreased cells viability in a concentration-dependent manner. MTT assay has shown that AuNPs stars significantly decreased the viability of hFOB 1.19 in concentration range $1.2-5 \mu \mathrm{g} / \mathrm{mL}, \mathrm{MG}-63$ in concentration $1.2-5 \mu \mathrm{g} / \mathrm{mL}$, and $143 \mathrm{~B}$ in concentration range $0.3-5 \mu \mathrm{g} / \mathrm{mL}$, whereas NR assay did not prove the cytotoxic effect of 
Fig. 2 UV-Vis spectra of AuNPs spheres, AuNPs rods and AuNPs stars

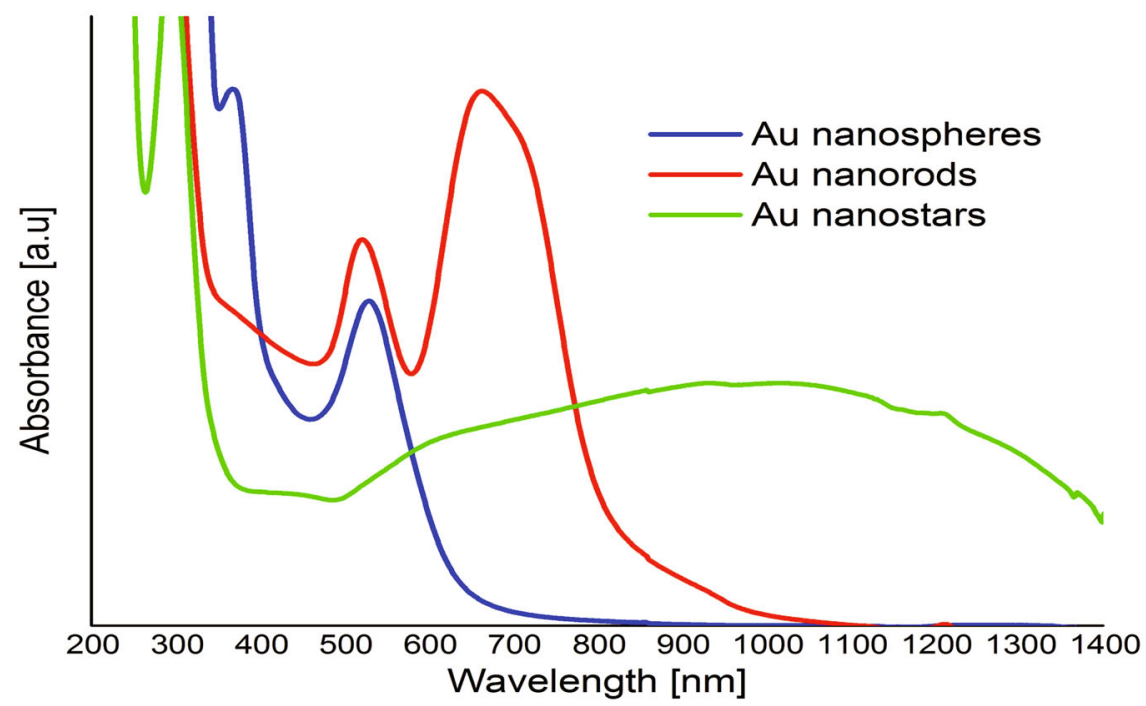

AuNPs stars in the lowest concentration $(0.3 \mu \mathrm{g} / \mathrm{mL})$. The most susceptible to cytotoxic effect of AuNPs stars were 143B cells. For the high concentration of AuNPs stars (2.5 and $5 \mu \mathrm{g} / \mathrm{mL}$ ) hFOB 1.19 cells were the most resistant one. After exposure to the low concentrations of AuNPs stars (0.3 and $0.6 \mu \mathrm{g} / \mathrm{mL})$ hFOB 1.19 and MG-63 cells had similar viability.

In MTT assay AuNPs rods significantly decreased the viability of hFOB 1.19, MG-63 and 143B cells. However, other assay (NR assay) has proven that hFOB 1.19 are resistant to cytotoxic effect of AuNP rods in concentration between $0.3-2.5 \mu \mathrm{g} / \mathrm{mL}, \mathrm{MG}-63$ in concentration range $0.3-$ $0.6 \mu \mathrm{g} / \mathrm{mL}$ and $143 \mathrm{~B}$ cells were resistant to AuNPs rods in concentration range of $0.3-1.2 \mu \mathrm{g} / \mathrm{mL}$.

AuNPs spheres exerted the smallest cytotoxic effect compared to other analysed nanoparticles. AuNPs spheres did not decrease the viability of hFOB1.19 and MG-63 cells, examined by MTT assay. AuNPs spheres, in concentration $5 \mu \mathrm{g} / \mathrm{mL}$, decreased the viability of $143 \mathrm{~B}$ cells but the effect was lower in comparison to other shapes. In NR assay AuNPs spheres did not have any statistically significant effect on the viability of hFOB1.19, MG63 and 143B cells in the analysed range of concentration. Non-linear regression analysis: $\log$ (inhibitor) vs. normalized response has been performed to calculate $\log \mathrm{IC}_{50}$ values (online resource 1). $\mathrm{IC}_{50}$ values for AuNPs stars are presented in Table 1. In order to show higher cytotoxicity of AuNPs stars against cancer cell lines compered to non-cancer cells.

\subsection{Protein level of Bax and $\mathrm{BCl}-2$}

We determined the impact of AuNPs rods and AuNPs stars on apoptosis-related protein. Level of proapoptotic protein
(Bax) and anti-apoptotic protein (Bcl-2) in MG-63 and 143B cells was demonstrated (Fig. 4). Due to lack cytotoxicity showed in NR assay and small cytotoxic effect (only in concentration $5 \mu \mathrm{g} / \mathrm{mL}$ ) against $143 \mathrm{~B}$ cells only showed by MTT assay, we did not determine the influence of AuNPs spheres on the level of protein, which are crucial regulators of cell death. AuNPs rods significantly increased the protein level of Bax in both cell lines, however, decreased the level of Bcl-2 was observed only in MG-63 cells. AuNPs stars significantly increased level of Bax and decreased level of Bcl-2 in all tested cell lines. For MG-63 cells AuNPs stars increased level of Bax protein in concentration between $0.1-1 \mu \mathrm{g} / \mathrm{mL}$ and decreased level of Bcl2 protein in concentration of $1 \mu \mathrm{g} / \mathrm{mL}$. AuNPs rods in concentration between $1-2 \mu \mathrm{g} / \mathrm{mL}$ increased level of Bax protein and in concentration of $2 \mu \mathrm{g} / \mathrm{mL}$ decreased level of Bcl-2 protein in MG-63 cells. AuNPs stars in concentration of $1 \mu \mathrm{g} / \mathrm{mL}$ increased level of Bax protein and decreased level of Bcl-2 protein on 143B cells. In 143B cells AuNPs rods in concentration of $2 \mu \mathrm{g} / \mathrm{mL}$ increased level of Bax protein, however AuNPs rods in tested range of concentration did not, statistically significant, influence level of Bcl-2 protein in 143B cells.

\subsection{TEM analysis}

TEM analysis have shown that AuNPs rods and AuNPs stars can be internalized by hTERT-HPNE cells and caused ultrastructure changes. AuNPs stars in concentration of 10 $\mu \mathrm{g} / \mathrm{mL}$ were internalized in the cytoplasm (Fig. 5c as well as in the nucleus of the cell (Fig. 5a). Additionally, we observed intensive vacuolization of the cytoplasm, and numerous autophagic vacuoles (Fig. 5a, b). In hTERT- 

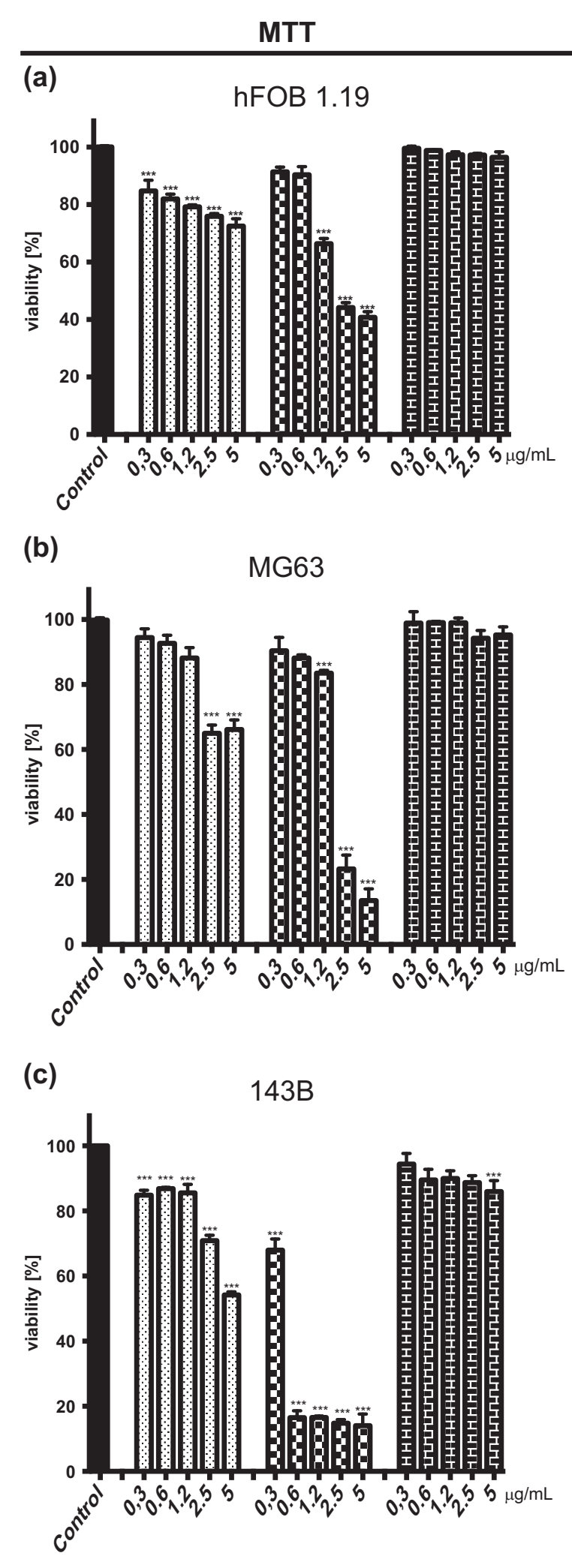

Control AuNPs rods

Fig. 3 Different shapes of AuNPs decreased cell viability in a concentration-dependent manner. Viability, measured by MTT test, of a hFOB1.19 cells, b MG-63, c 143B cells exposed to different shapes of AuNPs after $24 \mathrm{~h}$. Viability, measured by NR test, of $\mathbf{d}$ hFOB1.19

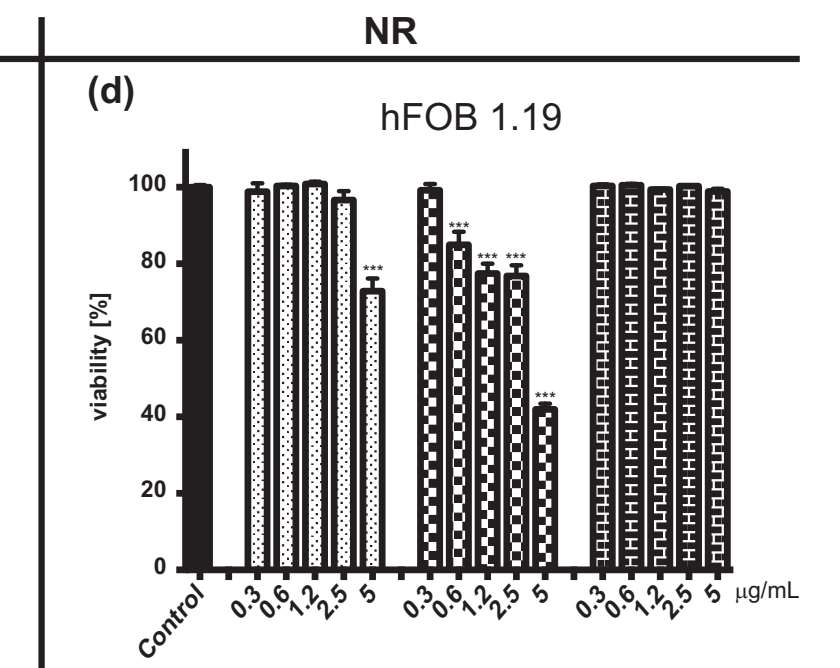

(e)

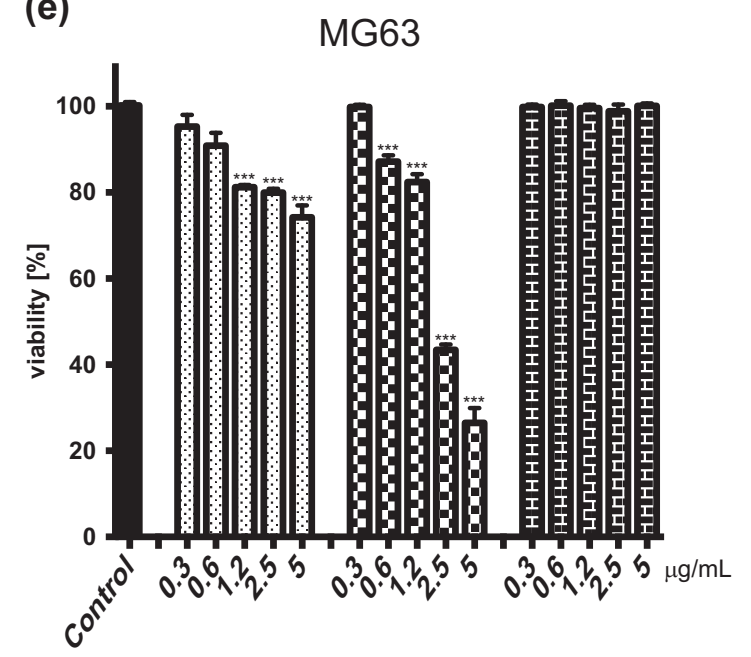

(f)

(f) $143 \mathrm{~B}$

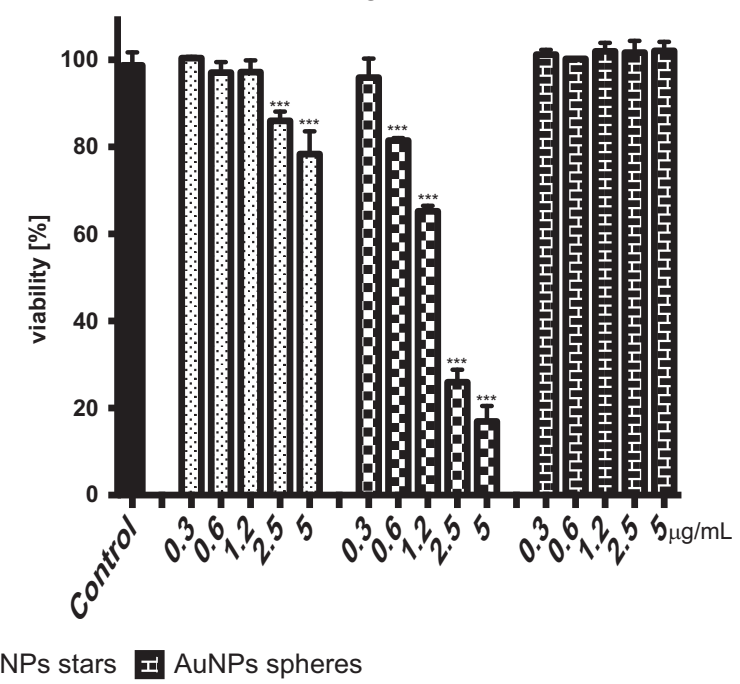

cells, e MG-63, f 143B cells exposed to different shapes of AuNPs after $24 \mathrm{~h}$. Data are presented as mean \pm SD. $* p<0.05, * * p<0.01$, $* * *, p<0.001$ 
HPNE cells after treatment with high $(50 \mu \mathrm{g} / \mathrm{mL})$ concentrations of AuNPs stars, we have observed major

Table $1 \mathrm{I}_{\mathrm{C} 50}$ for AuNPs stars

\begin{tabular}{llll}
\hline & HFOB1.19 & MG-63 & 143B \\
\hline MTT ASSAY & $1.241 \mu \mathrm{g} / \mathrm{mL}$ & $1.760 \mu \mathrm{g} / \mathrm{mL}$ & $0.4266 \mu \mathrm{g} / \mathrm{mL}$ \\
NR ASSAY & $3.961 \mu \mathrm{g} / \mathrm{mL}$ & $1.841 \mu \mathrm{g} / \mathrm{mL}$ & $1.396 \mu \mathrm{g} / \mathrm{mL}$ \\
\hline
\end{tabular}

impairment of the cells such as cell membrane rupture, cytoplasm vacuolization and general degeneration. AuNPs stars were present within cell debris (Fig. 6a-d). AuNPs rods in concentration of $10 \mu \mathrm{g} / \mathrm{mL}$ were found outside the cell along the cell membrane as well as internalized inside a small dense vesicles (endosomes) (Fig. 7a-f). Morphology of the cells treated with rods of AuNPs revealed normal/ unchanged rough endoplasmic reticulum and numerous autophagosomes. After treatment with higher concentrations of AuNPs rods $(50 \mu \mathrm{g} / \mathrm{mL})$ cells underwent major

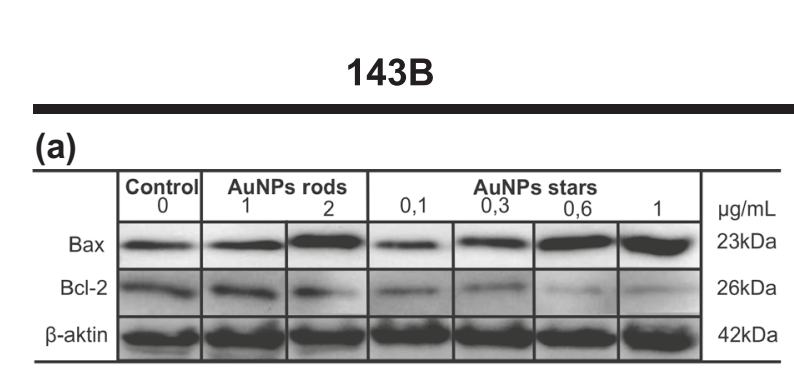

(b)

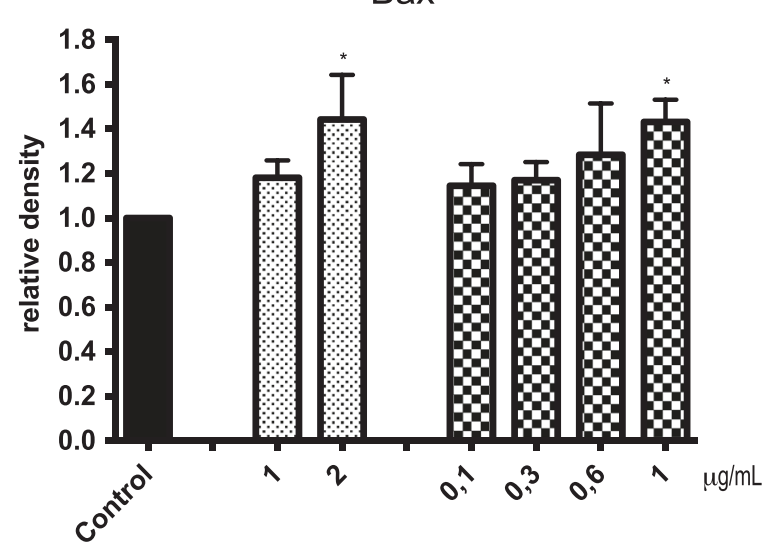

(c)

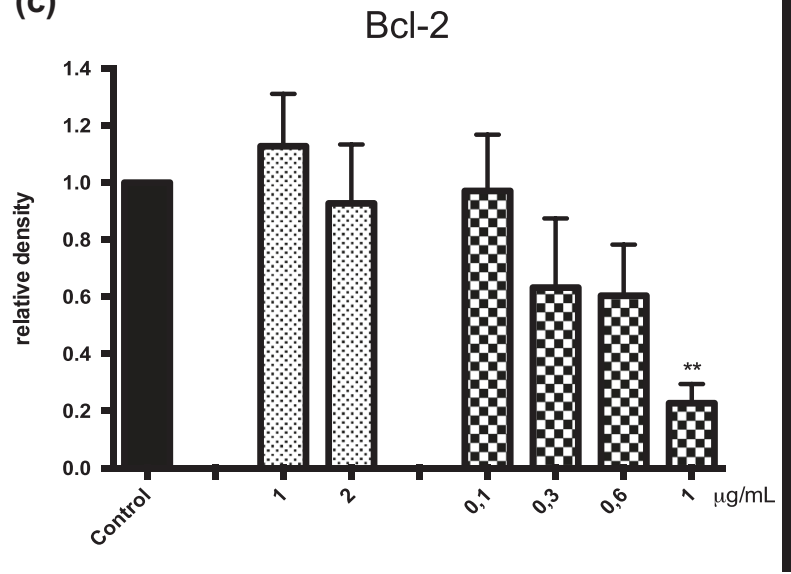

MG63

(d)

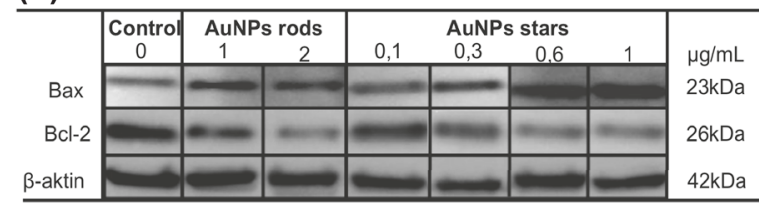

(e)

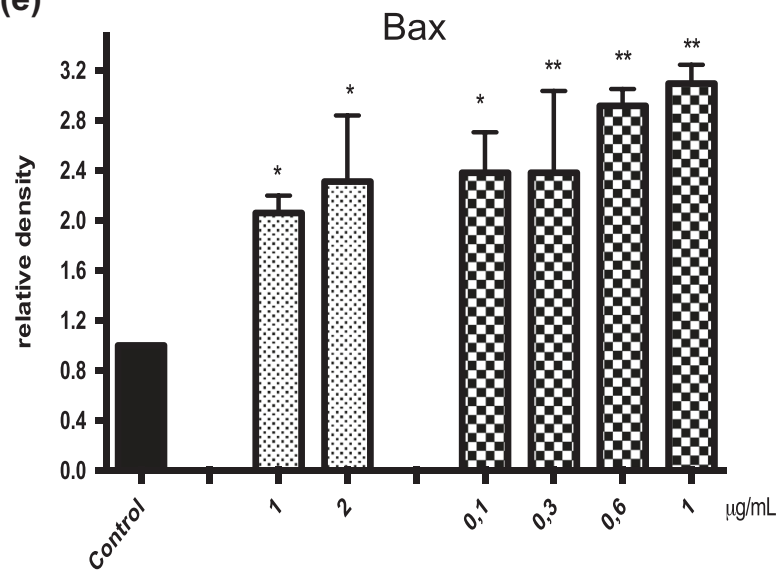

(f)

$\mathrm{Bcl}-2$

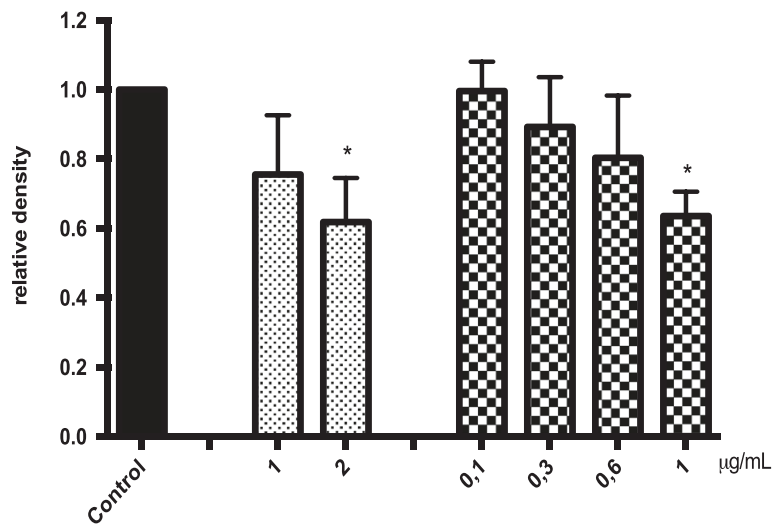

Control AuNPs rods $\mathbf{B}$ AuNPs stars

Fig. 4 Western-blot analysis of apoptosis-related protein level in 143B and MG-63 cells after $24 \mathrm{~h}$ of incubation with AgNPs. Representative Western blot analysis of Bax and Bcl-2 in a) 143Bcells and d MG-63.
Quantitive analysis of b, e Bax and c, f Bcl-2 proteins in 143B and MG-63 cells, respectively. Data are presented as mean \pm SD. ${ }^{*} p<$ $0.05, * * p<0.01$ 


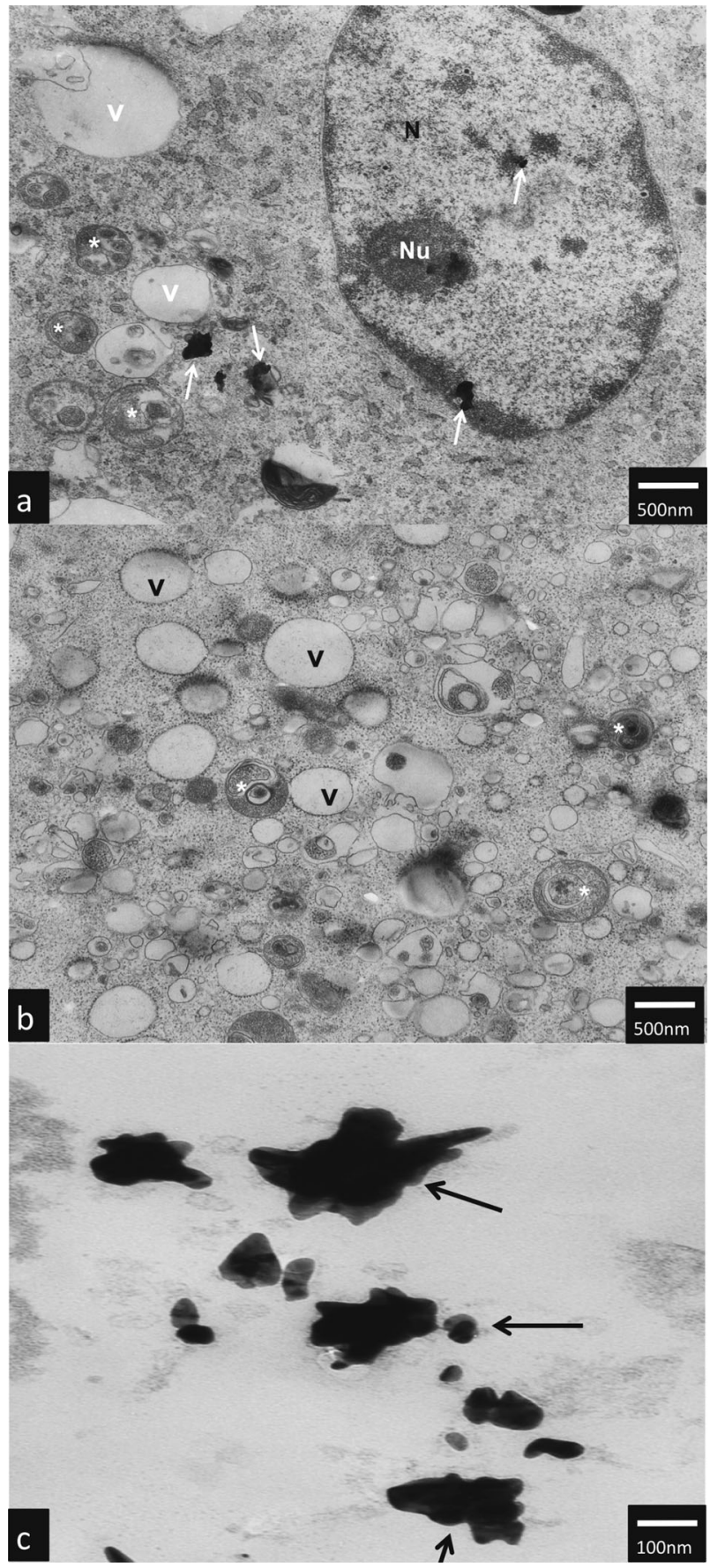

Fig. 5 Ultrastructure changes in hTERT-HPNE cells after $24 \mathrm{~h}$ incubation with $10 \mu \mathrm{g} / \mathrm{mL}$ AuNPs stars. AuNPs stars are indicated by arrows, $\mathrm{N}$ nulceus, NU nucleous, $\mathrm{V}$ vaculoes, *-authophagic vacuoles. The scale bar is present on the left side of each picture

degeneration. AuNPs rods have been observed along the cell membranes or cell debris (Fig. 8a-c). Some internalized of AuNPs rods have been found near the nuclear membrane (Fig. 8a). Despite the fact that the majority of cells have been seriously damaged, some cells remained normal. However, internalized AuNPs rods have been found in the cell perikaryon (Fig. 8d). The cell showed prominent rough endoplasmic reticulum as well as autophagic vacuole.

\section{Discussion}

The aim of our research was to determine the dependence of shape and concentration on the cytotoxicity of AuNPs against human fetal osteoblast and osteosarcoma cells. We also were focused on determining the type of programmed cell death induced by AuNPs We found that, AuNPs exerted their cytotoxic effect in a shape- and concentrationdependent manner. AuNPs stars were the most cytotoxic, whereas AuNPs spheres were the less cytotoxic ones. NR assay has shown that hFOB1.19 cells were the most resistant and 143B cells were the most susceptible to all examined AuNPs. In general, the NR assay has shown the higher viability of the cells than MTT test in the same condition. Our study has proven that both cytotoxicity of AuNPs and anti-cancer potential is shape-dependent. Thus, it should be taken in concern when designing NPs for biomedical usage, in order to increase safety of NPs application.

Osteosarcoma is highly metastatic mesenchymal cells carcinoma [19]. It is the third most common cancer in youth, so osteosarcoma is substantial epidemiological problem [19]. Typical treatment of this neoplasm consists of surgery, chemotherapy and radiotherapy, so therapy is crippling and the outcome is poor [19]. There is strong requirement for improved treatment, it has been demonstarted that nanoparticles may be interesting alternative for the 'classical' treatment [20]. Rahim et al., demonstrated that $24.3 \mathrm{~nm}$ spherical AuNPs capped with glication products (Schiff's base, Heyns products, fructosylamine etc.) inhibit growth of SaoS-2 (human osteosarcoma cell line) [21]. Similarly, Cebrain et al. have shown that $6 \mathrm{~nm}$ poly (ethylenimine) coated AuNPs decreased viability of SaoS-2 cells [22]. However, there was no study compering cytotoxicity of different shapes of AuNPs against osteosarcoma cells. In our study, we decided to use four cell lines hFOB1.19, hTERT-HPNE, MG-63 and 143B, because it has been proven that response to AuNPs exposure is very cell line dependent. [23]. We have chosen two osteosarcoma cell lines (MG-63 and 143B) because of their different characteristics. 143B cells proliferate and migrate more intensively than MG-63 cells, also 143B cells have higher tumorigenicity and colony forming ability [24, 25]. Taken together,143B cell line is more aggressive one. We used non-transformed and cancer cell lines, as studies suggest that cancer cells are more vulnerable to xenobiotics, due to faster and bigger uptake caused by hyper metabolism [26]. Non-transformed cells (hFOB1.19 and hTERT-HPNE) were used to assess the safety of potential in vivo 


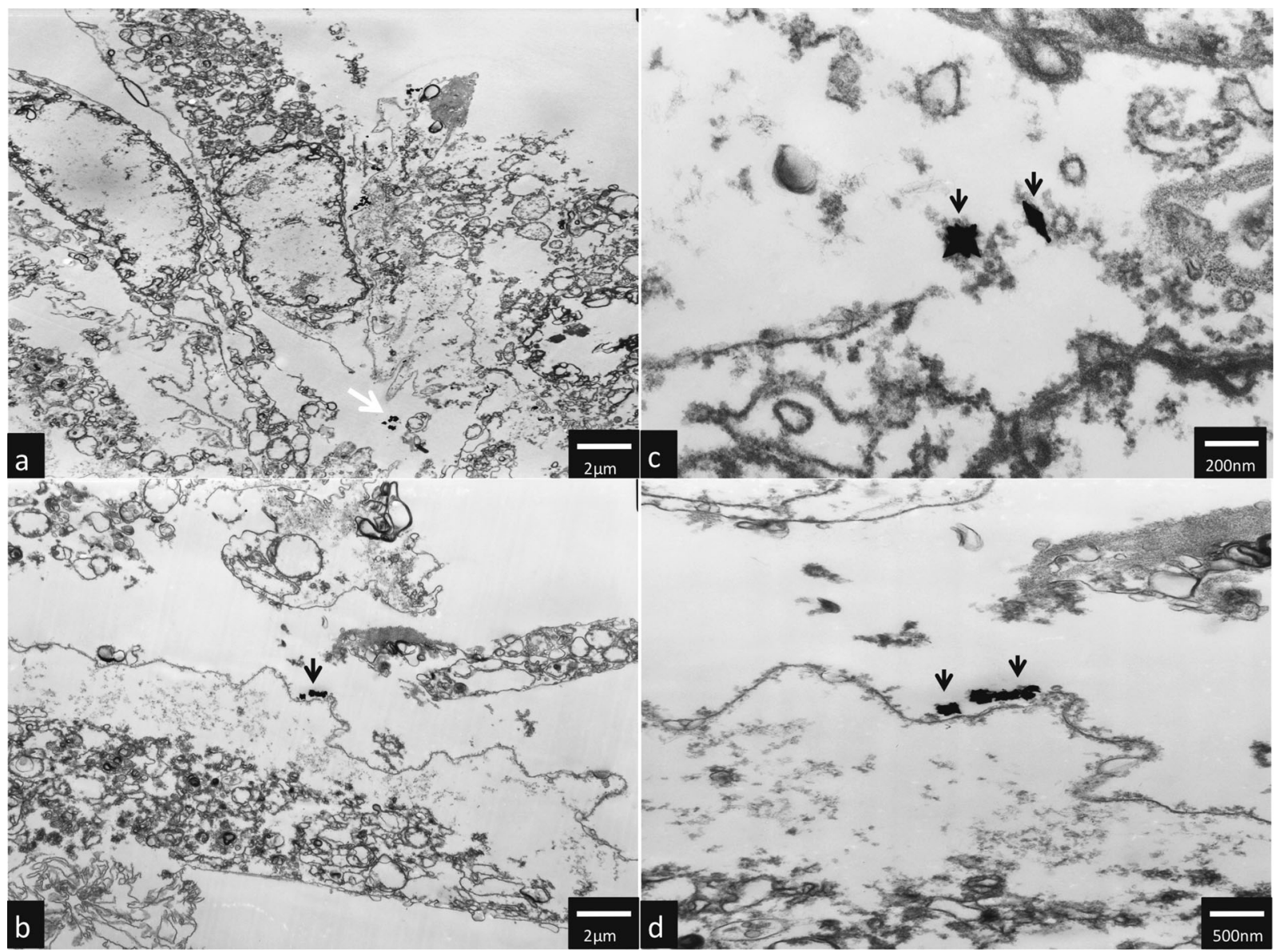

Fig. 6 Ultrastructure changes in hTERT-HPNE cells after $24 \mathrm{~h}$ incubation with $50 \mu \mathrm{g} / \mathrm{mL}$ AuNPs stars. AuNPs stars are indicated by arrows. The scale bar is present on the left side of each picture

application of AuNPs of different shapes. In other studies hTERT-HPNE cells were used as a comparison for selective cytotoxicity of tested compound against cancer cells. For example, Ramalho et al. compared the cytotoxicity of functionalized nanoparticles (PLGA-AuNPs) with potential anti-cancer activity against A549 cells (human lung carcinoma) and hTERT-HPNE [27]. Wada et al., also compered cytotoxicity of tested compunds on different cell lines CHO-K1 (chinese hamster ovary), HeLa (cervix cancer cells) and SH-SY5Y (neuroblast cells) [28].

\subsection{Cytotoxicity of AuNPs}

In order to provide the most reliable results, we decided to use two test: MTT and NR. NR assay is based on the ability of viable cells to uptake and accumulate dye in lysosomes and measured cellular membrane integrity [29]. MTT assay measured the activity of cellular NAD(P)H dependent oxidoreductase [29]. Decreased cell viability measured by MTT may indicate the cells underwent apoptosis [29, 30]. Because of different characteristic of both assays, they do not give equal results [31]. MTT test, as well as NR assay, are commonly used to assess the cytotoxicity of nanoparticles [32-34].

Recently, several groups have focused their attention on the cytotoxic activity of AuNPs [35, 36]. Size, shape, concentration, incubation time, synthesis method, surface functionalization, type of cells are thought to have an impact of cytotoxicity of AuNPs [37]. It has been proven that AuNPs can reduce the viability of human hepatocellular carcinoma [38] and human breast adenocarcinoma [39]. On the other hand, Gannon et al. have found that AuNPs in concentration between 1 and $67 \mu \mathrm{M} / \mathrm{L}$ are not cytotoxic to Hep3B (hepatocellular carcinoma) and Panc-1 (pancreatic epithelioid carcinoma) cells [40]. Patra et al., demonstrated that $33 \mathrm{~nm}$ AuNPs were toxic to human carcinoma lung cell line (A549 cells), and did not decrease viability of human hepatocellular carcinoma cells (Hepg-2) cells [41]. In other study it has been shown that 10 and $50 \mathrm{~nm}$ citrate coated AuNPs were not toxic to embryonic fibroblast [42].

Size of nanoparticles is important if considering their cytotoxicity. Generally, it seems that the larger the size of 


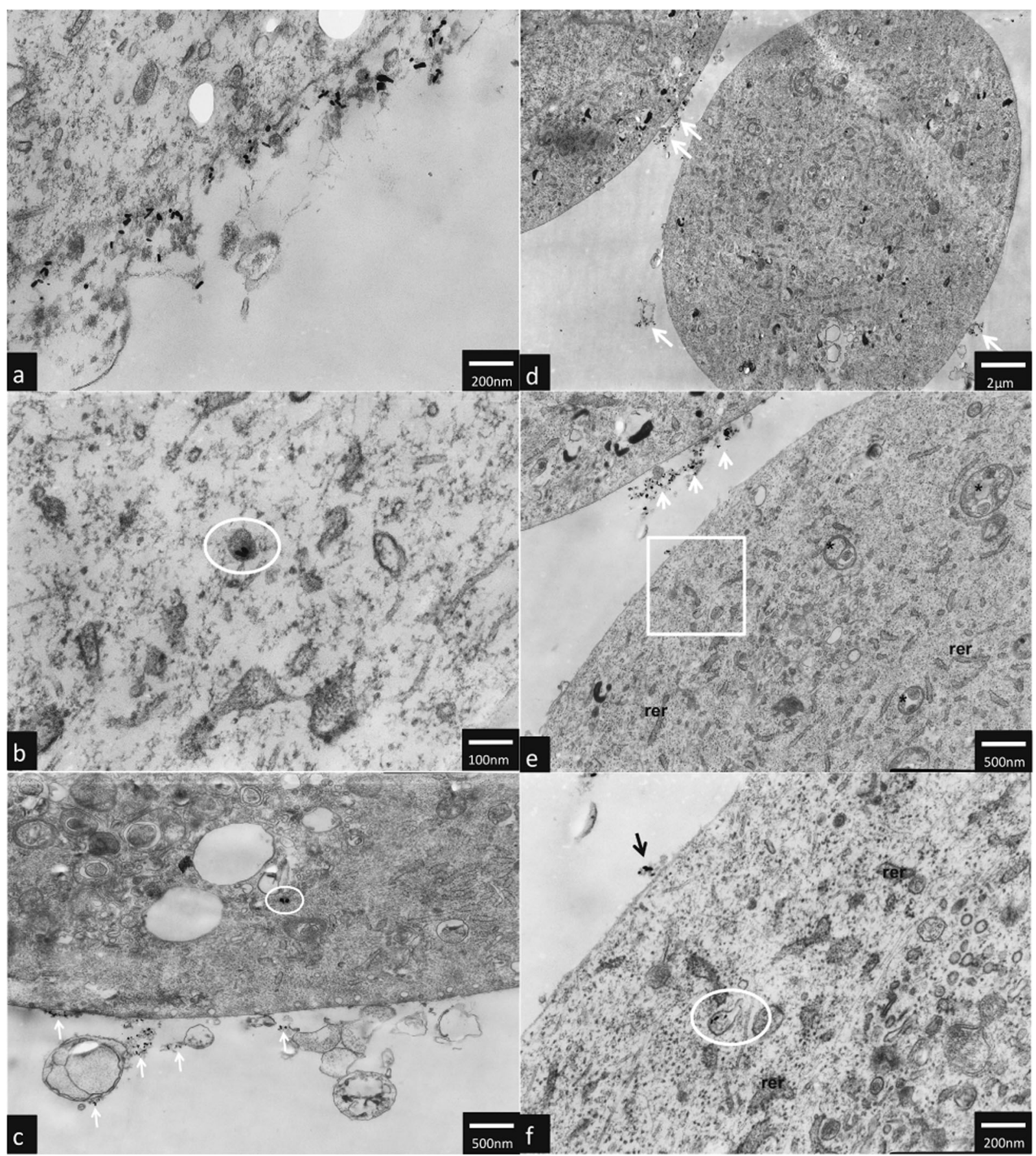

Fig. 7 Ultrastructure changes in hTERT-HPNE cells after $24 \mathrm{~h}$ incubation with $10 \mu \mathrm{g} / \mathrm{mL}$ AuNPs rods. AuNPs rods are indicated by arrows. Endosomes are circled, RER rough endoplasmatic reticulum, * authophagosomes. The scale bar is present on the left side of each picture

nanoparticles is the less cytotoxic they exerted [43]. Indeed, Coradeghini et al. have proven that $5 \mathrm{~nm}$ AuNPs were more cytotoxic in comparison to $15 \mathrm{~nm}$ AuNPs on Balb/3T3 (mouse fibroblast) cells. [44]. Similarly, Senut et al. have proven that $1.5 \mathrm{~nm}$ AuNPs are more cytotoxic to hESC (human embryonic stem cells) cells than 4 and $15 \mathrm{~nm}$ AuNPs [45]. However, Vetten et al., demonstrated that 20 $\mathrm{nm}$ AuNPs were more cytotoxic than $14 \mathrm{~nm}$ on BEAS-2B cells [46].

Although extensive knowledge about AuNPs cytotoxicity there is only few publication which has taken in concern shape of NPs as an important modulator of cytotoxicity. Our results suggest that AuNPs exerted their cytotoxicity mainly by influencing mitochondria 


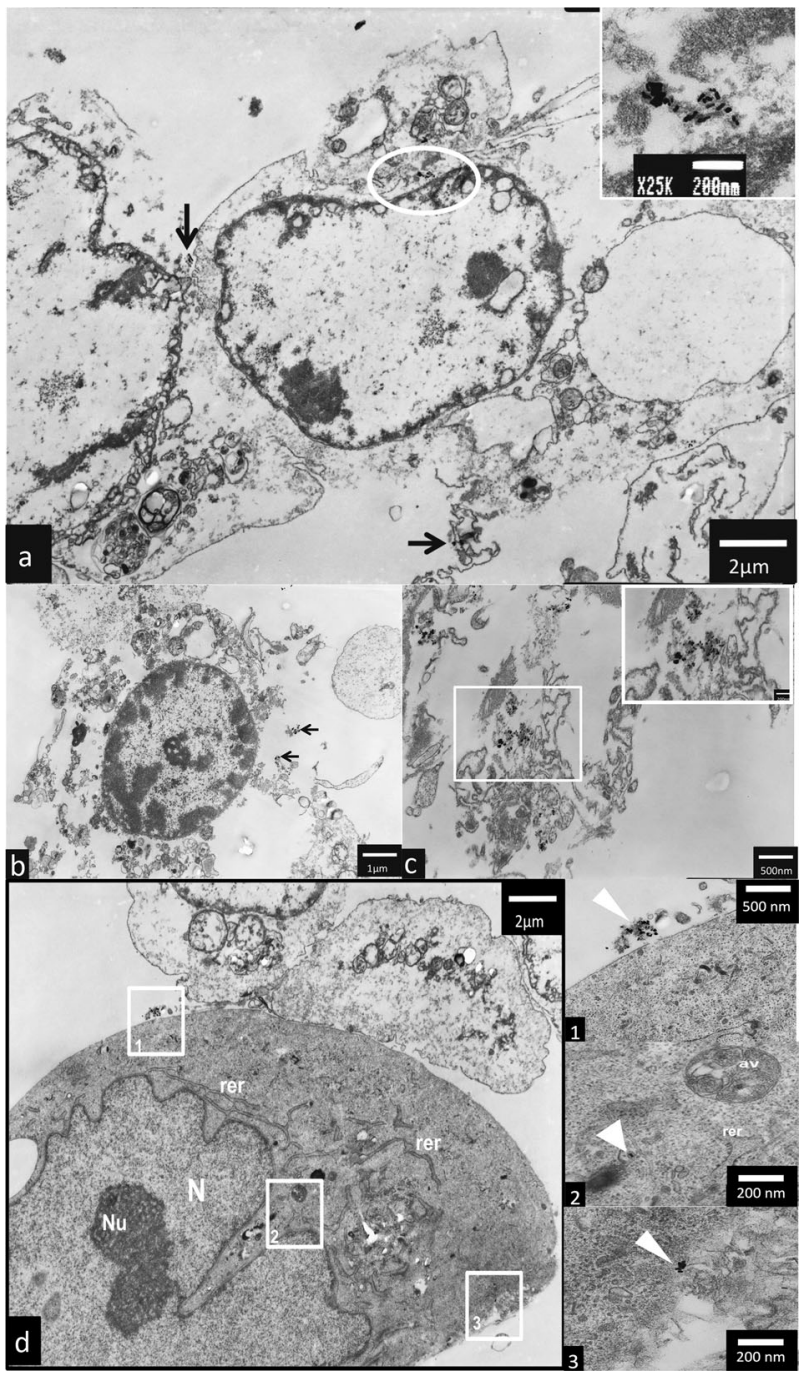

Fig. 8 Ultrastructure changes in hTERT-HPNE cells after $24 \mathrm{~h}$ incubation with $50 \mu \mathrm{g} / \mathrm{mL}$ AuNPs rods. AuNPs rods are indicated by arrows. AuNPs rods were founded near the nuclear membrane (boxed), RER rough endoplasmatic reticulum, AV authophagic vacuoles. The scale bar is present on the left side or at the bottom of each picture

functioning (MTT assay). However, the decreased viability of cells in NR assay suggested that NPs affected integrity of cellular membranes. It has been found that AuNPs rods exerted cytotoxic effect against canine MDCK (canine kidney epithelial cells) and HEp-2 (human HeLa contaminant epithelial cells) cell lines in a concentrationdependent manner (viability of cells was measured by MTT assay) [47]. In in vitro study, Favi et. al examined the impact of AuNPs rods (length $534 \pm 38 \mathrm{~nm}$, width $65 \pm 8$ $\mathrm{nm})$ on the viability of human dermal fibroblast. They observed that viability of the cells measured by MTS assay was decreased by $10-15 \%$ by AuNPs rods at concentration of $400 \mu \mathrm{g} / \mathrm{mL}$ [48]. In our study, AuNPs rods in concentration of $5 \mu \mathrm{g} / \mathrm{mL}$ decreased MG-63 cells viability (measured by MTT assay) by approximately $34 \%$ and 143B cells by $46 \%$. There are significant differences between our results and results presented by Favi et al. Firstly, they examined AuNPs rods in bigger size, and it has been proven that the bigger nanoparticles are the smaller effect on cells viability they have [43]. Furthermore, MTT and MTS test give similar but not equal results [49]. Other studies have proven that AuNPs rods decreased the viability of A549 cells (human lung adenocarcinoma cells) in a concentrationdependent manner. Further, it has been observed, consistent with our results, that AuNPs rods (length $40 \mathrm{~nm}$ ) are more cytotoxic than AuNPs spheres [47]. In several studies, it has demonstrated that AuNPs spheres did not have cytotoxic activity $[43,50]$.

\subsection{AuNPs-induced programmed cell death}

Choudhury et al., observed decreased level of Bcl-2 (antiapoptotic protein) and increased level of Bax (proapoptotic protein) in A549 cells after incubation with $40 \mathrm{~nm}$ AuNPs [51]. Selim et al., have reported that AuNPs may increase mRNA level of proapoptotic protein Bax, and decreased the level of a protein Bcl-2 in MCF-7 cells (human mammary adenocarcinoma) [39]. Similar results were presented for Hepg-2 cells incubated with $14.5 \mathrm{~nm}$ spherical AuNPs [52]. AuNPs rods are thought to induce apoptosis [30,47]. Furthermore, Chueh et al., have proven that AuNPs rods (length $10-40 \mathrm{~nm}$ ) induce apoptosis and autophagy in NIH3T3 cells (mouse fibroblast) [23]. Ding et al., have observed that spherical AuNPs (5, $13 \mathrm{~nm}$ ) caused autophagy in HK2 cells (human renal proximal tubular cells) [53]. Tang et al., have ascertained that AuNPs rods (width 23-26 nm, length $35-58 \mathrm{~nm}$ ) may cause necrosis of A549 cells. Furthermore, necrotic cells ratio increases in presence of high concentration of AuNPs rods (in concentration $>10$ $\mu \mathrm{g} / \mathrm{mL}$ ) [54]. Our results suggest that AuNPs rods and AuNPs stars may induced apoptosis in MG-63 and 143B cells, which is similar to observations made by several other authors [30, 47, 52].

\subsection{Cellular uptake and ultrastructure changes}

AuNPs may be internalized into cells and caused ultrastructural changes. Generally, molecules with positively charger surfaces have higher uptake ratio but lower intracellular stability in comparison to neutral or negatively charged molecules [55]. Furthermore, size of nanoparticles influence effectivity of their internalization [56]. There are two main mechanisms of AuNPs internalisation by membrane-bound vesicles [35] and endosomes [57]. Receptor-mediated endocytosis and fluid-phase endocytosis are the additional way of AuNPs internalisation [58]. Mironava et al., have demonstrated that way of AuNPs internalisation depends on diameter 
of AuNPs [10]. $45 \mathrm{~nm}$ AuNPs penetrate into human dermal fibroblast by clathrin-mediated endocytosis, while for $13 \mathrm{~nm}$ AuNPs phagocytosis is main way of internalisation [59]. It has been proven that AuNPs rods may be internalised by endosomes and vesicular bodies into human dermal fibroblasts (AuNPs rods: width 11.2-12.8 nm length 58-62 nm), colon adenocarcinoma and other cells [60, 61]. Other studies have shown that AuNPs are internalised by phagocytosis in A549 (AuNPs rods: width $23-26 \mathrm{~nm}$, length: $35-58 \mathrm{~nm}$ ) and HBL100 cells (AuNPs spheres 20-45 nm) [54, 58]. Furthermore, AuNPs can be found in the cytosol, lysosomes and perinuclear region either in form of aggregates or single NPs [53, 54, 58]. Exposition of A549 cells to AuNPs rods (width 23-26 nm, length $35-58 \mathrm{~nm}$ ) caused an increased number of lysosomes and swallowing of mitochondria [54]. The nucleus of A549 cells was not affected by AuNPs rods [54]. The data about uptake and cytotoxicity of AuNPs are inconsistent. Connor et al., have proven that AuNPs spheres may be taken up by K562 (chronic myelogenous leukemia) cells, but they are not cytotoxic [62]. Gannon et al. proved that AuNPs can be internalized by Panc-1 cells, however, TEM analysis has shown that AuNPs do not harm cellular organelles [40].

To the our knowledge this is the first study to compare shape- and size-dependent cytotoxic against human fetal osteoblast and osteosarcoma cells including the type of cell death and ultrastructure alterations caused by AuNPs.

\section{Conclusions}

In the present study we demonstrated that cytotoxicity of AuNPs is depended on the shape. We found that AuNPs stars are the most cytotoxic ones. Furthermore, we observed that cancer cells are more susceptible to AuNPs. For AuNPs in all investigated shapes, $\mathrm{IC}_{50}$ values were the lowest for $143 \mathrm{~B}$ cell line in comparison to hFOB 1.19 and MG-63 cell lines. We proved that AuNPs induced apoptosis in human osteosarcoma cells, both in 143B and MG-63. Moreover, AuNPs penetrated through the cell membrane and caused ultrastructural changes. Our study has proven that shape is important modulator of AuNPs cytotoxicity. Both anti-cancer potential and cytotoxicity of AuNPs is shape-dependent. It should be concerned in order to provide the highest efficiency with the highest safety of AuNPs application.

Acknowledgements The author AM acknowledges funding from Foundation for Polish Science (START. FNP). Authors KPS, EB, and IIS acknowledge funding from the Medical University of Gdansk (ST02-0046/07/259).

\section{Compliance with ethical standards}

Conflict of interest The authors declare that they have no conflict of interest.
Publisher's note: Springer Nature remains neutral with regard to jurisdictional claims in published maps and institutional affiliations.

Open Access This article is distributed under the terms of the Creative Commons Attribution 4.0 International License (http://crea tivecommons.org/licenses/by/4.0/), which permits use, duplication, adaptation, distribution, and reproduction in any medium or format, as long as you give appropriate credit to the original author(s) and the source, provide a link to the Creative Commons license, and indicate if changes were made.

\section{References}

1. Rai M, Ingle AP, Birla S, Yadav A, Santos CA, Dos. Strategic role of selected noble metal nanoparticles in medicine. Crit Rev Microbiol. 2015;00:1-24. https://doi.org/10.3109/1040841X. 2015.1018131

2. Elahi N, Kamali M, Baghersad MH. Recent biomedical applications of gold nanoparticles: a review. Talanta. 2018;184:537-56. https://doi.org/10.1016/j.talanta.2018.02.088

3. Banu H, Sethi DK, Edgar A, Sheriff A, Rayees N, Renuka N, et al. Doxorubicin loaded polymeric gold nanoparticles targeted to human folate receptor upon laser photothermal therapy potentiates chemotherapy in breast cancer cell lines. J Photochem Photobiol B Biol. 2015;149:116-28. https://doi.org/10.1016/j.jphotobiol.2015. 05.008

4. Lee U, Yoo C-J, Kim Y-J, Yoo Y-M. Cytotoxicity of gold nanoparticles in human neural precursor cells and rat cerebral cortex. J Biosci Bioeng. 2016;121:341-4. https://doi.org/10.1016/ j.jbiosc.2015.07.004

5. Draz MS, Shafiee H. Applications of gold nanoparticles in virus detection. Theranostics. 2018;8:1985-2017. https://doi.org/10. $7150 /$ thno. 23856

6. Hussain MM, Samir TM, Azzazy HME. Unmodified gold nanoparticles for direct and rapid detection of Mycobacterium tuberculosis complex. Clin Biochem. 2013;46:633-7. https://doi.org/ 10.1016/j.clinbiochem.2012.12.020

7. Murphy CJ, Thompson LB, Alkilany AM, Sisco PN, Boulos SP, Sivapalan ST, et al. The many faces of gold nanorods. J Phys Chem Lett. 2010;1:2867-75. https://doi.org/10.1021/jz100992x

8. Ahn S, Lee IH, Kang S, Kim D, Choi M, Saw PE, et al. Gold nanoparticles displaying tumor-associated self-antigens as a potential vaccine for cancer immunotherapy. Adv Healthc Mater. 2014;3:1194-9. https://doi.org/10.1002/adhm.201300597

9. Wang F, Yu L, Monopoli MP, Sandin P, Mahon E, Salvati A, et al. The biomolecular corona is retained during nanoparticle uptake and protects the cells from the damage induced by cationic nanoparticles until degraded in the lysosomes. Nanomedicine. 2013;9:1159-68. https://doi.org/10.1016/j.nano.2013.04.010

10. Mironava T, Hadjiargyrou M, Simon M, Rafailovich MH. Gold nanoparticles cellular toxicity and recovery: adipose derived stromal cells. Nanotoxicology. 2014;8:189-201. https://doi.org/ 10.3109/17435390.2013.769128

11. Woźniak A, Malankowska A, Nowaczyk G, Grześkowiak BF, Tuśnio K, Słomski R, et al. Size and shape-dependent cytotoxicity profile of gold nanoparticles for biomedical applications. J Mater Sci Mater Med. 2017;28:1-11. https://doi.org/10.1007/s10856017-5902-y

12. Gołabiewska A, Malankowska A, Jarek M, Lisowski W, Nowaczyk G, Jurga S, et al. The effect of gold shape and size on the properties and visible light-induced photoactivity of $\mathrm{Au}-\mathrm{TiO} 2$. Appl Catal B Environ. 2016;196:27-40. https://doi.org/10.1016/j. apcatb.2016.05.013

13. Zielinska E, Tukaj C, Radomski MW, Inkielewicz-Stepniak I. Molecular mechanism of silver nanoparticles-induced human 
osteoblast cell death: protective effect of inducible nitric oxide synthase inhibitor. PLoS One. 2016;11:e0164137 https://doi.org/ 10.1371/journal.pone. 0164137

14. Bradford MM. A rapid and sensitive method for the quantitation of microgram quantities of protein utilizing the principle of protein-dye binding. Anal Biochem. 1976;72:248-54. https://doi. org/10.1016/0003-2697(76)90527-3

15. Nikoobakht B, El-Sayed M. Preparation and growth mechanism of gold nanorods (NRs) using seed-mediated growth method. Chem Mater. 2003;15:1957-62. https://doi.org/10.1021/ $\mathrm{Cm} 0207321$

16. Kooij ES, Ahmed W, Hellenthal C, Zandvliet HJW, Poelsema B. From nanorods to nanostars: tuning the optical properties of gold nanoparticles. Colloids. Surf A Physicochem Eng Asp. 2012;413:231-8. https://doi.org/10.1016/j.colsurfa.2012.01.041

17. Zhong X, Chai YQ, Yuan R. A novel strategy for synthesis of hollow gold nanosphere and its application in electrogenerated chemiluminescence glucose biosensor. Talanta. 2014;128:9-14. https://doi.org/10.1016/j.talanta.2014.03.071

18. Navarro JRG, Liotta A, Faure A-C, Lerouge F, Chaput F, Micouin $\mathrm{G}$, et al. Tuning dye-to-particle interactions toward luminescent gold nanostars. Langmuir. 2013;29:10915-21. https://doi.org/10. 1021/la402222c

19. Luetke A, Meyers PA, Lewis I, Juergens H. Osteosarcoma treatment-where do we stand? A state of the art review. Cancer Treat Rev. 2014;40:523-32. https://doi.org/10.1016/j.ctrv.2013.11.006

20. Sha B, Gao W, Han Y, Wang S, Wu J, Xu F, et al. Potential application of titanium dioxide nanoparticles in the prevention of osteosarcoma and chondrosarcoma recurrence. J Nanosci Nanotechnol. 2013;13:1208-11. https://doi.org/10.1166/jnn.2013.6081

21. Rahim M, Iram S, Khan MS, Khan MS, Shukla AR, Srivastava $\mathrm{AK}$, et al. Glycation-assisted synthesized gold nanoparticles inhibit growth of bone cancer cells. Colloids Surf B Biointerfaces. 2014;117:473-9. https://doi.org/10.1016/j.colsurfb.2013.12.008

22. Cebrian V, Martin-Saavedra F, Yague C, Arruebo M, Santamaria J, Vilaboa N. Size-dependent transfection efficiency of PEI-coated gold nanoparticles. Acta Biomater. 2011;7:3645-55. https://doi. org/10.1016/j.actbio.2011.06.018

23. Chueh PJ, Liang R-Y, Lee Y-H, Zeng Z-M, Chuang S-M. Differential cytotoxic effects of gold nanoparticles in different mammalian cell lines. J Hazard Mater. 2014;264:303-12. https:// doi.org/10.1016/j.jhazmat.2013.11.031

24. Yuan J, Ossendorf C, Szatkowski JP, Bronk JT, Yaszemski M, Bolander ME, et al. Osteoblastic and osteolytic human osteosarcomas can be studied with a new xenograft mouse model producing spontaneous metastases. Cancer Invest. 2009;27:43542. https://doi.org/10.1080/07357900802491477.Osteoblastic

25. Lauvrak SU, Munthe E, Kresse SH, Stratford EW, Namløs HM, Meza-Zepeda LA, et al. Functional characterisation of osteosarcoma cell lines and identification of mRNAs and miRNAs associated with aggressive cancer phenotypes. $\mathrm{Br} \mathrm{J}$ Cancer. 2013;109:2228-36. https://doi.org/10.1038/bjc.2013.549

26. Sun DJ, Liu Y, Lu DC, Kim W, Lee JH, Maynard J, et al. Endothelin-3 growth factor levels decreased in cervical cancer compared with normal cervical epithelial cells. Hum Pathol. 2007;38:1047-56. https://doi.org/10.1016/j.humpath.2006.12.015

27. Ramalho MJ, Loureiro JA, Gomes B, Frasco MF, Coelho MAN, Carmo Pereira M. PLGA nanoparticles as a platform for vitamin D-based cancer therapy. Beilstein J Nanotechnol. 2015;6: 1306-18. https://doi.org/10.3762/bjnano.6.135

28. Wada T, Hanyu T, Nozaki K, Kataoka K, Kawatani T, Asahi T, et al. Antioxidant activity of Ge-132, a synthetic organic germanium, on cultured mammalian cells. Biol Pharm Bull. 2018. https://doi.org/10.1248/bpb.b17-00949

29. Husøy T, Syversen T, Jenssen J. Comparisons of four in vitro cytotoxicity tests: the MTT assay, NR assay, uridine incorporation and protein measurements. Toxicol Vitr. 1993;7:149-54. https:// doi.org/10.1016/0887-2333(93)90125-O

30. Tian F, Clift MJD, Casey A, del Pino P, Pelaz B, Conde J, et al. Investigating the role of shape on the biological impact of gold nanoparticles in vitro. Nanomed (Lond). 2015;10:2643-57. https://doi.org/10.2217/nnm.15.103

31. Borenfreund E, Babich H, Martin-Alguacil N. Comparisons of two in vitro cytotoxicity assays - the neutral red (NR) and tetrazolium MTT tests. Toxicol Vitr. 1988;2:1-6. https://doi.org/10. 1016/0887-2333(88)90030-6

32. Ahamed M, Akhtar MJ, Alhadlaq HA, Khan MAM, Alrokayan SA. Comparative cytotoxic response of nickel ferrite nanoparticles in human liver HepG2 and breast MFC-7 cancer cells. Chemosphere. 2015;135:278-88. https://doi.org/10.1016/j.chemosphere. 2015.03.079

33. Liu YK, Ye J, Han QL, Tao R, Liu F, Wang W. toxicity and bioactivity of cobalt nanoparticles on the monocytes. Orthop Surg. 2015;7:168-73. https://doi.org/10.1111/os.12180

34. Zielinska E, Zauszkiewicz-Pawlak A, Wojcik M, InkielewiczStepniak I. Silver nanoparticles of different sizes induce a mixed type of programmed cell death in human pancreatic ductal adenocarcinoma. Oncotarget. 2017;9:4675-97.

35. Liu Z, Wu Y, Guo Z, Liu Y, Shen Y, Zhou P, et al. Effects of internalized gold nanoparticles with respect to cytotoxicity and invasion activity in lung cancer cells. PLoS One. 2014;9:1-11. https://doi.org/10.1371/journal.pone.0099175

36. Huang D, Zhou H, Liu H, Gao J. The cytotoxicity of gold nanoparticles is dispersity-dependent. Dalt Trans. 2015;44:179115. https://doi.org/10.1039/C5DT02118A

37. Khlebtsov N, Dykman L. Biodistribution and toxicity of engineered gold nanoparticles: a review of in vitro and in vivo studies. Chem Soc Rev. 2011;40:1647-71. https://doi.org/10.1039/ C0CS00018C

38. Paino IMM, Marangoni VS, de Oliveira R de CS, Antunes LMG, Zucolotto V. Cyto and genotoxicity of gold nanoparticles in human hepatocellular carcinoma and peripheral blood mononuclear cells. Toxicol Lett. 2012;215:119-25. https://doi.org/10. 1016/j.toxlet.2012.09.025

39. Selim ME, Hendi AA. Gold nanoparticles induce apoptosis in MCF-7 human breast cancer cells. Asian Pac J Cancer Prev. 2012;13:1617-20. https://doi.org/10.7314/APJCP.2012.13.4.1617

40. Gannon CJ, Patra CR, Bhattacharya R, Mukherjee P, Curley SA. Intracellular gold nanoparticles enhance non-invasive radiofrequency thermal destruction of human gastrointestinal cancer cells. J Nanobiotechnology. 2008;6:2 https://doi.org/10.1186/ 1477-3155-6-2

41. Patra HK, Banerjee S, Chaudhuri U, Lahiri P, Dasgupta AK. Cell selective response to gold nanoparticles. Nanomedicine. 2007;3:111-9. https://doi.org/10.1016/j.nano.2007.03.005

42. Qu Y, Lü X. Aqueous synthesis of gold nanoparticles and their cytotoxicity in human dermal fibroblasts-fetal. Biomed Mater. 2009;4:2-7. https://doi.org/10.1088/1748-6041/4/2/025007

43. Skalska J, Strużyńska J. Toxic effects of silver nanoparticles in mammals - does a risk of neurotoxicity exist? Folia Neuropathol. 2015;53:281-300. https://doi.org/10.5114/fn.2015.56543

44. Coradeghini R, Gioria S, García CP, Nativo P, Franchini F, Gilliland D, et al. Size-dependent toxicity and cell interaction mechanisms of gold nanoparticles on mouse fibroblasts. Toxicol Lett. 2013;217:205-16. https://doi.org/10.1016/j.toxlet. 2012.11.022

45. Senut M-C, Zhang Y, Liu F, Sen A, Ruden DM, Mao G. Sizedependent toxicity of gold nanoparticles on human embryonic stem cells and their neural derivatives. Small. 2016;12:631-46. https://doi.org/10.1002/smll.201502346

46. Vetten MA, Tlotleng N, Tanner Rascher D, Skepu A, Keter FK, Boodhia $\mathrm{K}$, et al. Label-free in vitro toxicity and uptake 
assessment of citrate stabilised gold nanoparticles in three cell lines. Part Fibre Toxicol. 2013;10:1-15. https://doi.org/10.1186/ 1743-8977-10-50

47. Zhang Y, Xu D, Li W, Yu J, Chen Y. Effect of size, shape, and surface modification on cytotoxicity of gold nanoparticles to human HEp-2 andcanine MDCK Cells. J Nanomater. 2012. https://doi.org/10.1155/2012/375496

48. Favi PM, Valencia MM, Elliott PR, Restrepo A, Gao M, Huang $\mathrm{H}$, et al. Shape and surface chemistry effects on the cytotoxicity and cellular uptake of metallic nanorods and nanospheres. J Biomed Mater Res A. 2015;103:3940-55. https://doi.org/10.1002/ jbm.a.35518

49. Wang P, Henning SM, Heber D. Limitations of MTT and MTSbased assays for measurement of antiproliferative activity of green tea polyphenols. PLoS One. 2010. https://doi.org/10.1371/journal. pone.0010202

50. Freese C, Uboldi C, Gibson MI, Unger RE, Weksler BB, Romero IA, et al. Uptake and cytotoxicity of citrate-coated gold nanospheres: comparative studies on human endothelial and epithelial cells. Part Fibre Toxicol. 2012;9:23 https://doi.org/10.1186/17438977-9-23

51. Choudhury D, Xavier PL, Chaudhari K, John R, Dasgupta AK, Pradeep T, et al. Unprecedented inhibition of tubulin polymerization directed by gold nanoparticles inducing cell cycle arrest and apoptosis. Nanoscale. 2013;5:4476 https://doi.org/10. $1039 / \mathrm{c} 3 \mathrm{nr} 33891 \mathrm{f}$

52. Shanmugasundaram T, Radhakrishnan M, Gopikrishnan V, Kadirvelu K, Balagurunathan R. Biocompatible silver, gold and silver/gold alloy nanoparticles for enhanced cancer therapy: in vitro and in vivo perspectives. Nanoscale. 2017;9:16773-90. https://doi.org/10.1039/C7NR04979J

53. Ding FA, Li YP, Liu J, Liu L, Yu WM, Wang Z, et al. Overendocytosis of gold nanoparticles increases autophagy and apoptosis in hypoxic human renal proximal tubular cells. Int $\mathbf{J}$ Nanomed. 2014;9:4317-30. https://doi.org/10.2147/ijn.s68685

54. Tang Y, Shen Y, Huang L, Lv G, Lei C, Fan X, et al. In vitro cytotoxicity of gold nanorods in A549 cells. Environ Toxicol
Pharmacol. 2015;39:871-8. https://doi.org/10.1016/j.etap.2015. 02.003

55. Landgraf L, Müller I, Ernst P, Schäfer M, Rosman C, Schick I, et al. Comparative evaluation of the impact on endothelial cells induced by different nanoparticle structures and functionalization. Beilstein J Nanotechnol. 2015;6:300-12. https://doi.org/10.3762/ bjnano. 6.28

56. Jiang W, Kim BYS, Rutka JT, Chan WCW. Nanoparticlemediated cellular response is size-dependent. Nat Nanotechnol. 2008;3:145-50. https://doi.org/10.1038/nnano.2008.30

57. Liu Y, He M, Niu M, Zhao Y, Zhu Y, Li Z, et al. Delivery of vincristine sulfate-conjugated gold nanoparticles using liposomes: a light-responsive nanocarrier with enhanced antitumor efficiency. Int J Nanomed. 2015;10:3081-95. https://doi.org/10.2147/IJN. S79550

58. Amarnath K, Mathew NL, Nellore J, Siddarth CRV, Kumar J. Facile synthesis of biocompatible gold nanoparticles from Vites vinefera and its cellular internalization against HBL-100 cells. Cancer Nanotechnol. 2011;2:121-32. https://doi.org/10.1007/ s12645-011-0022-8

59. Mironava T, Hadjiargyrou M, Simon M, Jurukovski V, Rafailovich $\mathrm{MH}$. Gold nanoparticles cellular toxicity and recovery: effect of size, concentration and exposure time. Nanotoxicology. 2010;4:120-37. https://doi.org/10.3109/17435390903471463

60. Favi PM, Gao M, Johana Sepúlveda Arango L, Ospina SP, Morales M, Pavon JJ, et al. Shape and surface effects on the cytotoxicity of nanoparticles: gold nanospheres versus gold nanostars. J Biomed Mater Res - Part A. 2015;103:3449-62. https://doi.org/10.1002/jbm.a.35491

61. Afrooz ARMN, Sivalapalan ST, Murphy CJ, Hussain SM, Schlager JJ, Saleh NB. Spheres vs. rods: the shape of gold nanoparticles influences aggregation and deposition behavior. Chemosphere. 2013;91:93-8. https://doi.org/10.1016/j.chemosphere.2012.11.031

62. Connor EE, Mwamuka J, Gole A, Murphy CJ, Wyatt MD. Gold nanoparticles are taken up by human cells but do not cause acute cytotoxicity. Small. 2005;1:325-7. https://doi.org/10.1002/smll. 200400093 